University of Nebraska - Lincoln

DigitalCommons@University of Nebraska - Lincoln

Faculty Publications in the Biological Sciences

Papers in the Biological Sciences

$10-1921$

New Species and Collections of Arrhenuri: 1921

Ruth Marshall

University of Nebraska - Lincoln

Follow this and additional works at: https://digitalcommons.unl.edu/bioscifacpub

Part of the Life Sciences Commons

Marshall, Ruth, "New Species and Collections of Arrhenuri: 1921" (1921). Faculty Publications in the Biological Sciences. 22.

https://digitalcommons.unl.edu/bioscifacpub/22

This Article is brought to you for free and open access by the Papers in the Biological Sciences at DigitalCommons@University of Nebraska - Lincoln. It has been accepted for inclusion in Faculty Publications in the Biological Sciences by an authorized administrator of DigitalCommons@University of Nebraska - Lincoln. 


\title{
NEW SPECIES AND COLLECTIONS OF ARRHENURI: 1921.
}

\author{
BY \\ Ruth Marshall \\ Rockford College
}

The genus Arrhenurus, the largest group of the water mites, continues to yield new material from collections in lake regions. The new species described in this paper came from regions as far apart as Canada and China; while additional notes on already described species are based on material secured in several states of northeastern United States, some of them from new localities. Through the kindness of Professor N. Gist Gee, of Soochow University, material was secured for the description of new species from China. Professor Frank Smith and Dr. H. R. VanCleave, of the University of Illinois, were good enough to contribute some material from Michigan, New York and Massachusetts. Through the interest of Dr. R. A. Muttkowski an opportunity was given for the examination of some collections of the Biological Station of the United States Bureau of Fisheries at Fairport, Iowa; and more recently the author was privileged to see some collections of Dr. F. A. Stromsten, of the University of Iowa. The author's own collections from the Muskoka Lake region of Ontario, together with other material from various sources, form the basis of a preliminary account of the genus Arrhenurus as it has been found in Canada. This topic will be discussed first.

Practically the only account of the water mites of Canada so far is that contained in a paper by Dr. F. Koenike, "Nordamerikanische $\mathrm{Hy}$ drachniden," and a revision of this paper, "A Revision of my 'Nordamerikanische Hydrachniden.", The descriptions were based upon material sent to him by Dr. J. B. Tyrell, of Toronto, and were collected in Alberta and British Columbia, near the international line. Of the thirty species listed by Dr. Koenike, four were Arrhenuri and new species. These were A. lautus, $A$. interpositus (a young male), $A$ setiger and $A$. krameri. The last named species has since been found by the author and further notes are given in this paper. In addition to this, one new species is now added for Canada (A. uniformis nov. spec.), and four more are recorded for the first time, as follows. A. americanus Mar. and $A$. manubriator Mar. were found by the author at Parry Sound and A. americanus var. major Mar. in a small lake near Bala, Ontario. A. marshalli Piers., the most widely distributed species, had previously been found in material from Long Point, Canada, in some collections of the United States Fish Commission.

In the descriptions of species which follow the Canadian material will be discussed first. 
Arrhenurus uniformis nov. spec.

Pl. IX, fig. 1-3.

This species resembles $A$. scutiliformis Mar. and belongs in the group of "long-tailed" Arrhenuri in which the very long and rather simple appendix is decidedly narrower at the end than it is at the base. The outline of the body is approximately circular; the enclosed dorsal area and the appendix are moderately high and rounded. Details of structure given in the figures show this to be a new species. The last joint of the fourth leg is long and slim; the spur on the fourth joint is moderately developed.

The single male on which this description is based is $1.33 \mathrm{~mm}$. long and $0.73 \mathrm{~mm}$. wide. The color is dull olive green. It was found in a small lake near Long Lake, at Bala, Ontario, August 25, 1920.

Arrhenurus krameri Koenike.

Pl. IX, fig. 7-9.

The author has already recorded (1908) the finding o a mite from Oregon which appeared to be $A$. krameri. Drawings of this specimen are now given for the first time and its identity with the single male from British Columbia on which Dr. Koeinke's description was based seems to be established. It is slightly smaller, however, measuring only $1.29 \mathrm{~mm}$. A dorsal view is shown, which did not appear in the original paper, together with the lateral view and a drawing of the palpus.

Arrhenurus simulans nov. spec.

Pl. X, fig. 17-21.

Material sent to the author by Dr. H. J. Van Cleave from collections in Dump Lake, Woods Hole, Massachusetts, contained sixty individuals of this species. It was at first thought to be $A$. krameri, altho a larger form, the length being $1.45 \mathrm{~mm}$. and the extreme width, $0.83 \mathrm{~mm}$. The males bear some resemblance also to $A$. rectangularis Mar., especially when a comparison is made of the side views of the long appendix, the end of which in the three named species shows a double scallop, one part above the other. The body of the new species is conspicuously elevated where it joins the appendix. The wing-shaped genital areas are rather small and the ends of the line enclosing the dorsal area are far behind them on the appendix. Twenty-seven males were present. The color in the preservation is dull brown green.

Over half of the individuals in the collection were females; the examination of the palpi shows that they belong to this species. The body of A. simulans fem. is broadly ovate. The epimeral plates are relatively small; the third and fourth have about the same width throughout, the two posterior groups being well separated from each other and from the genital area. The fourth epimera are narrow, scarcely wider than the third. The genital plates are of nearly uniform width and extend straight out from the aperature, which is large. The body is $1.32 \mathrm{~mm}$. in length. 


\section{Arhenurus pseudosetiger nov. spec.}

$$
\text { Pl. IX, fig. 4-6. }
$$

In a former paper (1910) the author identified as $A$. setiger Koen. an individual from Madison, Wisconsin. But a more careful study of this specimen shows that it belongs to another, though closely related species, which will be designated as $A$. pseudosetiger. The body proper is stouter than it is shown in Dr. Koenike's figures of the Canadian species, being nearly circular in outline, not oblong, and the appendix is smaller. The dorsal enclosed area runs over on the appendix and is depressed. The entire length of the body is $0.8 \mathrm{~mm}$., the greatest width, in the region of the fourth leg, $0.7 \mathrm{~mm}$. The color is deep brick red.

\section{Arrhenurus trifoliatus Marshall}

Pl. IX, fig. 10-12.

It is not often that the collector succeeds in securing a large number of Arrhenuri at any one time; it is still more unusual to find any one species in numbers large enough to make possible a thorough examination of all structures and to identify with certainty the females of the species. Collections made by the author in the marshy sloughs at Burlington, Wisconsin, July 5, 1919, consisted largely of individuals of the rather uncommon species, A. trifoliatus, twenty-five males and fifteen females being secured. It is now seen that the earlier description of the species (1908) did not show completely the details of the appendix of the male. As seen in Fig. 10, a young male, a delicate bladder-like structure, A, is attached to either side of the stout petiole, a structure which is easily in ured in preservation.

The female, which is now described for the first time, is broadly oval in form. The posterior groups of epimera are close together and the genital area lies immediately behind them. The genital wing-shaped areas are unusual in form, the outer ends curving strongly upward. The length of the body is $1.15 \mathrm{~mm}$., the extreme width, $1.05 \mathrm{~mm}$.

A. major was represented in this Burlington collection by one male. The Lake Beulah region which was visited at the same time yielded four species of Arrhenuri A. marshalli, A. megalurus, A. americanus and $A$. reflexus, the latter having the unusual color of orange red.

\section{Arrhenurus compactilis Marshall}

Pl. X, fig. 13-16.

This somewhat rare species was found in collections from Fairport, Iowa, and again in the collections of Professor Frank Smith from Douglas Lake, Michigan. This new material adds two states to the range of the species and makes possible a more complete study of its structure. Drawings of the palpus and the last leg are now given. The latter is seen to be very characteristic of this group of stout bodied petiolated Arrhenuri in having a long fourth joint with a conspicuous spur ending in a tuft of curved hairs, while the fifth and sixth segments of this appendage are short. 
The female of the species is now known from the study of the palpi which agree in all details with those of the male except that they are somewhat larger, as usual. The body is stout and oval and measures $1.3 \mathrm{~mm}$. in length. Details of the dorsal and ventral suriaces are shown in the figures.

The collections of water mites from the Biological Station at Fairport, summer of 1917, have already been referred to. They were secured from small lakes in the vicinity of the Station and were rich in Arrhenuri. This material is especially interesting since there have been no previous records of Arrhenuri from Iowa that the author is aware of. Nine species were found, as follows:
A. marshalli Piers.
A. fissicornis Mar.
A. americanus Mar.
A. compactilis Mar.
A. americanus var. major Mar.
A. laticaudatus Mar.
A. apetiolatus Piers.
A. dentipetiolatus Mar.
A. birgei Mar.

The last named species is rare, only two other specimens, from Colorado, having been recorded.

The collections of Dr. F. A. Stromsten, mentioned in the introduction, add $A$. lyriger Mar. to the list.

The following descriptions of two new species of Arrhenuri from China continue the study of the water mites of the region of Soochow which was begun in a former paper (1919), and are made possible through the continued interest of Professor N. Gist Gee who furnished the material.

\section{Arrhenurus soochowensis nov. spec.}

Pl. XI, fig. 22-25

The new species belongs to a type of Arrhenuri which is seen in $A$. kraepelini Koen. described from Java, a type apparently common in the Asiatic members of the genus. This is the type of $A$. forpicatus Neum. of Europe, represented in America by $A$. lyriger Mar. It is characterized by a deep incision in the end of the appendix, the hyaline appendix lying on the dorsal side of this.

The single individual upon which this description is based has these characteristics well marked. The appendix is relatively long; the median incision runs into a round opening over which lies the large and highly developed hyaline structures, closely resembling the same parts in $A$. limbatus Koen. of Madagascar. The dorsal enclosed area of the body is rather small and the line which encloses it is not quite closed. The fourth joint of the fourth leg has a short spur. The fourth joint of the palpus is unusually broad at the distal end. This is a small mite, $0.8 \mathrm{~mm}$. long and $0.5 \mathrm{~mm}$. wide. The color is dull green. The specific name refers to the locality where it was found. 


\section{Arrhenurus geei nov. spec.}

Pl. XI, fig. 26-29

This species resembles $A$. madaraszi Daday found in Ceylon and belongs to the forpicatus group mentioned under the last species. The appendix is small and narrow but well developed; its median incision is large at the upper end. The hyaline appendix is an oblong structure; on either side of it is developed a delicate claw-like piece. The body is broad; the enclosed dorsal area is large, the line enclosing it not quite closed posteriorly. The fourth leg lacks the spur on the fourth joint. The palpus, as in the related species, has a broad fourth joint. The single male on which this description is based is $0.73 \mathrm{~mm}$. long and $0.56 \mathrm{~mm}$. broad. The species is dedicated to Professor Gee.

Koenike, F.

\section{Literature Cited}

1895. Nordamerikanische Hydrachniden. Abh. natur. Vereins Bremen, 13:167-226.

1912. A Revision of My "Nordamerikanische Hydrachniden." Trans. Canadian Institute, Toronto, p. 281-296.

Marshall, $R$.

1908. The Arrhenuri of the United States. Trans. Am. Mic. Soc. 28: 85-134.

$\rightarrow$ 1910. New Studies of the Arrhenrui. Trans. Am. Mic. Soc., 29:97-110.

1919. New Species of Water Mites of the Genus Arrhenurus. Trans. Am. Mic. Soc., $38: 225-281$.

\section{Explanation of the Plates}

Plate IX

1. Arrhenurus uniformis, dorsal view.

2. Arrhenurus uniformis, genital area.

3. Arrhenurus uniformis, lateral view.

4. Arrhenurus pseudosetiger, dorsal view.

5. Arrhenurus pseudosetiger, lateral view.

6. Arrhenurus pseudosetiger, left palpus.

7. Arrhenurus krameri, dorsal view.

8. Arrhenurus krameri, lateral view.

9. Arrhenurus krameri, left palpus.

10. Arrhenurus trifoliatus, appendix of young male.

11. Arrhenurus trifoliatus, female, epimera.

12. Arrhenurus trifoliatus, right palpus.

Plate X.

13. Arrhenurus compactilis, female, dorsal view.

14. Arrhenurus compactilis, fèmale, ventral view.

15. Arrhenurus compactilis, male, part of left fourth leg, the last three joints rotated.

16. Arrhenurus compactilis, right palpus.

17. Arrhenurus simulans, female, epimera.

18. Arrhenurus simulans, male, dorsal view.

19. Arrhenurus simulans, appendix, ventral view. 
20. Arrhenurus simulans, lateral view.

21. Arrhenurus simulans, left palpus.

\section{Plate XI.}

22. Arrhenurus soochowensis, dorsal view.

23. Arrhenurus soochowensis, lateral view.

24. Arrhenurus soochowensis, ventral view.

25. Arrhenurus soochowensis, left palpus.

26. Arrhenurus geei, lateral view.

27. Arrhenurus geei, dorsal view.

28. Arrhenurus geei, appendix, ventral view.

29. Arrhenurus geei, left palpus. 


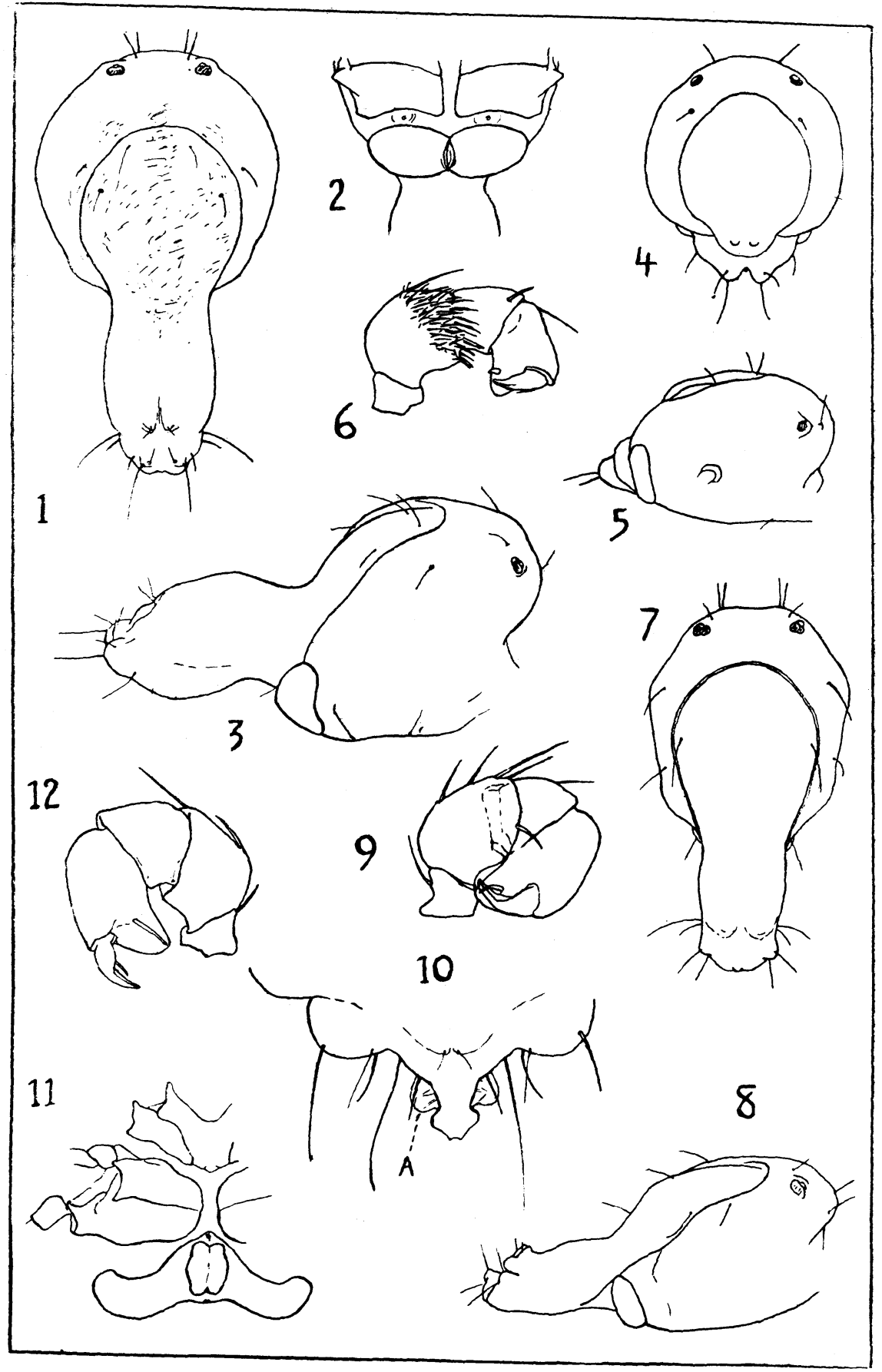

PLATE IX 


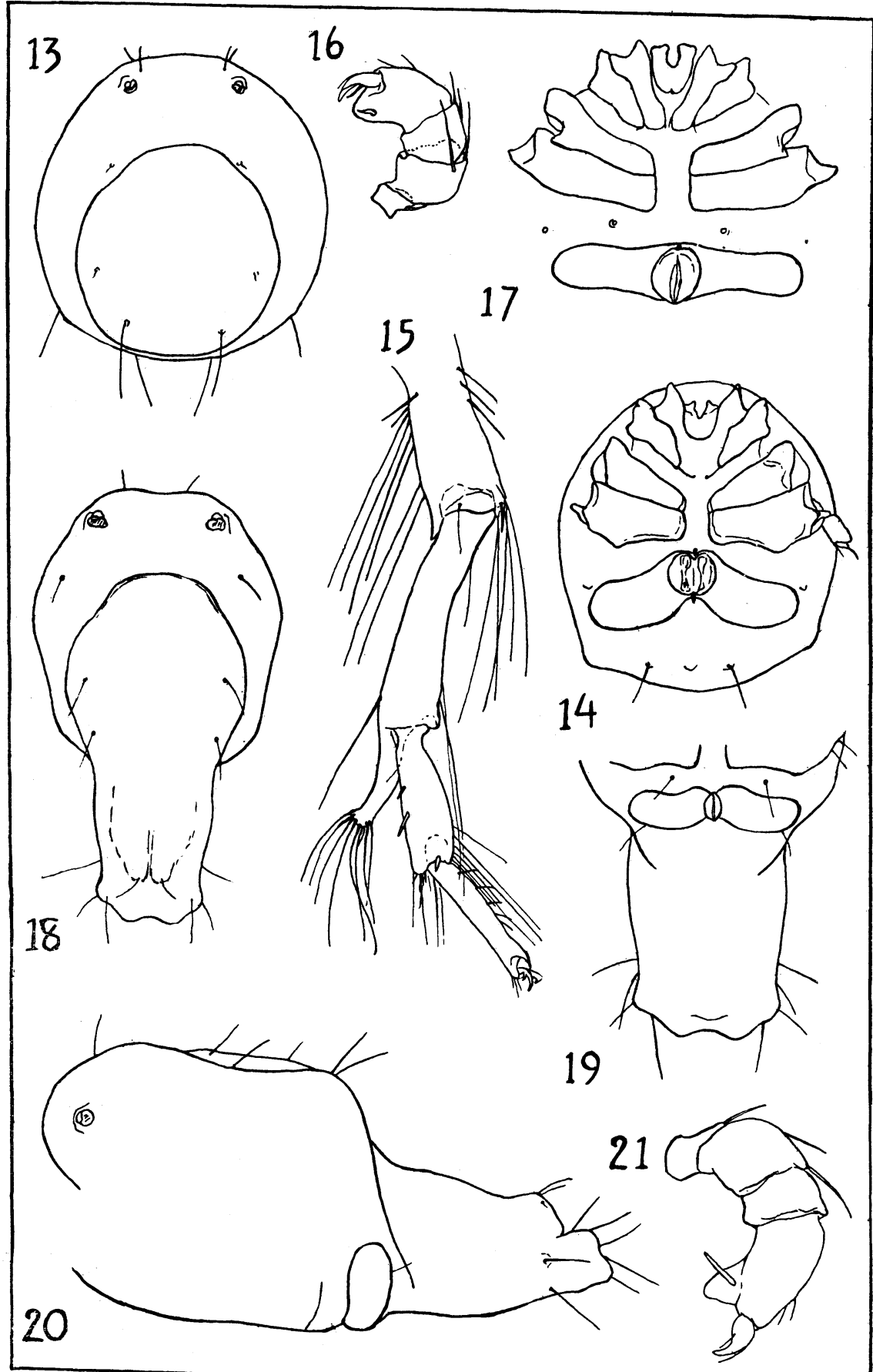

PLATE X 


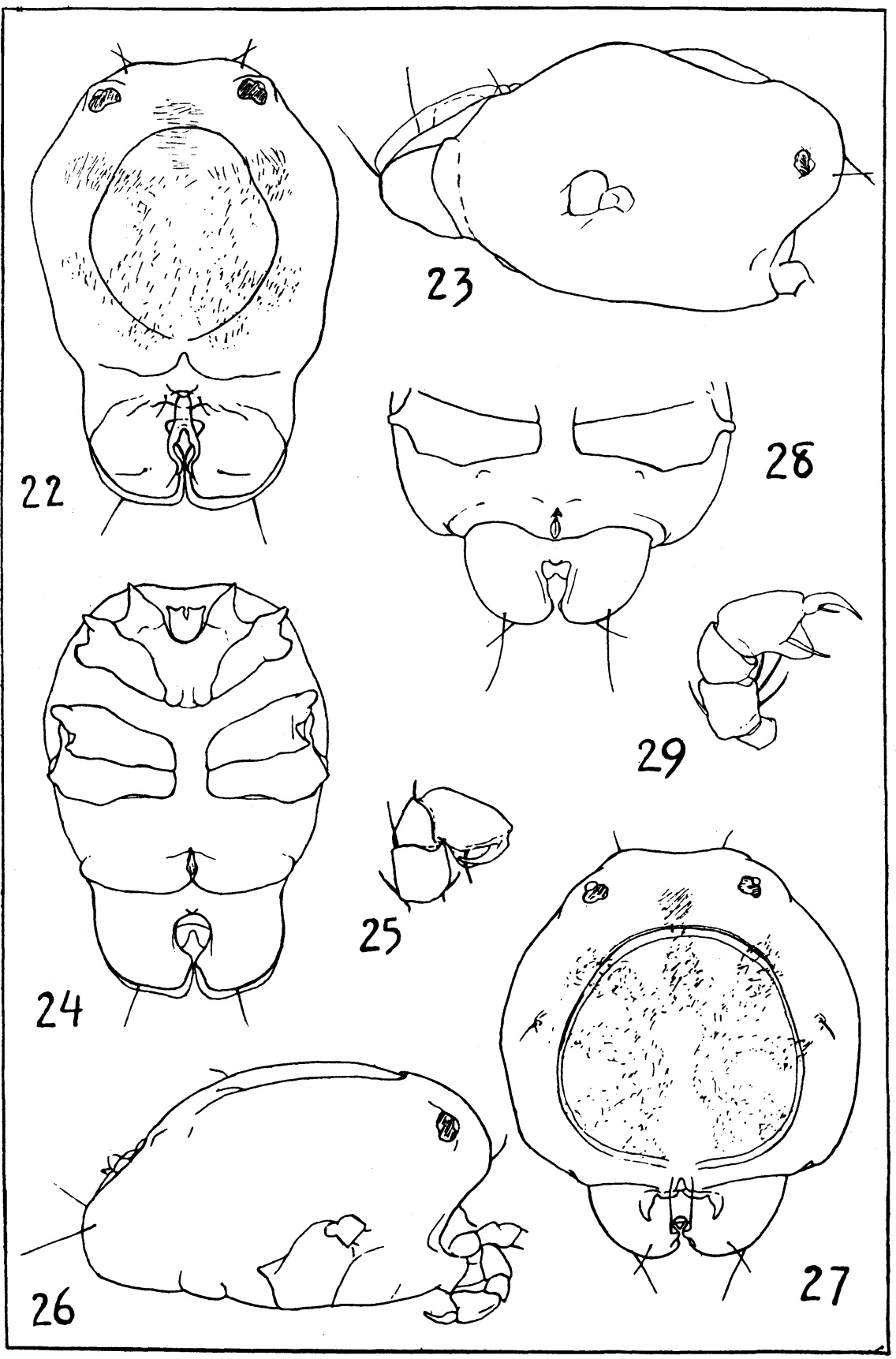

PLATE XI 